\title{
ERBB2 Mutation Analysis Testing Method
}

National Cancer Institute

\section{Source}

National Cancer Institute. ERBB2 Mutation Analysis Testing Method. NCI Thesaurus.

Code C158885.

A request to enter the specific molecular analysis method used to detect and identify mutations in the ERBB2 gene. 